\title{
Tari Nawung Sekar: Kemampuan Sosial Anak Digital Natives di Era Revolusi Industri 4.0
}

\author{
Maria Denok Bekti Agustinigrum ${ }^{\circledR}{ }^{\boxplus}$, Sri Sayekti², Dwi Hardiyanti ${ }^{3}$, Dwi Asih Kumala \\ Handayani $^{4}$, Sri Redjeki ${ }^{5}$ \\ Pendidikan Guru Pendidikan Anak Usia Dini, Universitas Ivet Semarang \\ DOI: $\underline{10.31004 / \text { obsesi.v5i2.1004 }}$
}

\begin{abstract}
Abstrak
Era Revolusi Industri 4.0 menciptakan kondisi anak usia dini menjadi anak-anak digital natives. Anak-anak digital natives adalah anak usia dini yang memiliki kecenderungan tergantung pada teknologi namun memiliki kemampuan sosial yang rendah. Hal tersebut dikarenakan mereka tidak memiliki ruang yang cukup untuk mengembangkan kemampuan berinteraksi dan mengembangkan kemampuan sosial emosinya. Penelitian ini terjadi sebelum masa pandemic Covid-19 sehingga masih diadakannya kegiatan-kegiatan tatap muka (luring). Metode penelitian yang digunakan adalah meode penelitian kualitatif dengan pendekatan fenomenologis dengan subyek penelitian anak usia dini berusia 3-6 tahun. Metode pengumpulan data yang dipergunakan adalah observasi, wawancara dan studi dokumentasi. Hasil penelitian ditemukan bahwa tari Nawung Sekar mampu menstimulasi kemampuan sosial anak digital natives.
\end{abstract}

Kata Kunci: nawung sekar; digital native; sosial emosi; revolusi industri.

\begin{abstract}
The era of the Industrial Revolution 4.0 created conditions for early childhood to become digital natives. Digital natives children are early childhood who tend to depend on technology but have low social skills. This is because they do not have sufficient space to develop their ability to interact and develop their social emotional skills. This research occurred before the Covid-19 pandemic, so face-to-face (offline) activities were still held. The research method used is a qualitative research method with a phenomenological approach with early childhood research subjects aged 3-6 years. The data collection methods used were observation, interview and documentation study. The results showed that the Nawung Sekar dance was able to stimulate the social skills of digital natives children.
\end{abstract}

Keywords: nawung sekar; digital native; social emotions; industrial revolution

Copyright (c) 2021 Maria Denok Bekti Agustinigrum, Sri Sayekti, Dwi Hardiyanti, DAK Handayani ${ }^{4}$, Sri Redjeki ${ }^{5}$ $\triangle$ Corresponding author :

Email Address : mdenok14@gmail.com (Semarang, Jawa Tengah, Indonesia)

Received 31 January 2021, Accepted 5 Feabruary 2021, Published 9 February 2021 


\section{PENDAHULUAN}

Era revolusi industry 4.0 pada masyarakat Indonesia nampak pada pesatnya perkembangan teknologi di segala aspek kehidupan. Penggunaan teknologi di segala aspek menjadi sebuah bagian dari kehidupan modern, kehidupan yang mengglobal baik secara individu maupun komunal. Gaya hidup modern tersebut menjadi sebuah gaya hidup yang dilakukan secara sukarela oleh masyarakat Indonesia agar dapat diterima sebagai bagian dari masyarakat dunia.

Gaya hidup tersebut merupakan hal yang baik mengingat teknologi diciptakan guna membantu kehidupan manusia menjadi lebih mudah dan nyaman. Beberapa keuntungan yang nampak adalah masyarakat jadi lebih mudah untuk mengakses informasi, menghemat waktu dan tenaga karena munculnya teknologi transpotasi, memudahkan dalam perekonomian karena munculnya system penjualan digital, dan beberapa kemudahan lainnya yang muncul (Agustinigrum, 2020).

Kemudahan-kemudahan dalam hidup ternyata mampu memberikan dampak negative yang timbul di masyarakat. Munculnya pola interaksi baru antar manusia melalui system telekomunikasi yang baru, yaitu internet. Pola interaksi baru tersebut disebut dengan pola staying conneted. Interaksi sosial yang dilakukan oleh manusia antar manusia tersebut tidak harus dilakukan secara face to face atau saling bertatap muka namun dapat dilakukan melalui perangkat gadget dan bahkan menghadirkan dunia dalam genggaman mereka tanpa harus keluar menuju dunia.

Budaya baru staying conneted ternyata berdampak buruk bagi kesehatan anak, anakanak yang terlalu lama menghabiskan waktu dengan gadget dapat terganggu pertumbuhan fisiknya. Pertumbuhan fisik ynak berada pada masa perkembangan, maka perlu adanya stimulasi dengan benar melalui gerak yang terarah dan tepat (Korde-Nayak, 2017).

Dampak lain dari budaya staying conneted pada anak, yaitu anak-anak menjadi tidak tertarik bermain bersama teman sebayanya karena lebih tertarik bermain dengan permainan digitalnya. Anak-anak tidak mendapatkan kesempatan pengalaman bermain dengan teman sebayanya. Dalam ilmu psikologi anak, bermain adalah kebutuhan anak. Melalui bermain anak dapat belajar, belajar hal baru baik pengetahuan maupun pengalaman berinteraksi secara nyata dengan lingkungan dan anak lain (Badu, 2011).

Hasil penelitian yang dilakukan oleh Jin Shin pada anak-anak usia dini di Korea Selatan ditemukan bahwa anak-anak menjadi lebih sulit berkonsentrasi dalam dunia nyata. Dunia nyata adalah dunia dimana anak tumbuh dan berkembang secara nyata melalui interaksi dengan lingkungan dan masyarakat. Kesulitan yang muncul tersebut dikarenakan anak-anak terbiasa mengadakan komunikasi satu arah sehingga saat berinteraksi dengan anak lain dan lingkungan mereka kesulitan dikarenakan tidak adanya pengalaman dua arah memunculkan error atau destruksi dalam berkomunikasi (Yee jin Shin, 2014).

Ketidakmampuan berinteraksi dengan teman sebaya dan lingkungan berdampak pada kegagalan berkomunikasi dan bersosialisasi anak pada saat dewasa. Hal tersebut dikarenakan anak sebagai individu yang bertumbuh kembang menjadi dewasa nantinya akan menjadi bagian dari masyarakat. Maka kemampuan interaksi menjadi penting dikarenakan berguna dalam eksistensinya di kehidupan mendatang, bahkan mampu memberikan kontribusi besar bagi terwujudnya masyarakat yang mapan dan berkarakter (Gifary \& Kurnia N, 2015).

Kemampuan bersosialisasi anak dalam masyarakat adalah sebuah potensi yang sejak lahir sudah dimiliki anak sebagai sebuah kemampuan sosial emosi. Kemampuan sosial emosi anak ini menjadi matang dan berguna bagi anak untuk bertahan hidup dalam sebuah masyarakat kelak di kemudian hari jika distimulasi dengan benar dan tepat. Situasi yang sudah peneliti ungkapkan tentang situasi anak digital natives menunjukkan bahwa anak usia dini memiliki permasalahan dalam kesempatan memiliki pengalaman berinteraksi dengan teman sebaya dan lingkungannya. Lalu untuk dapat memecahkan masalah tersebut dibutuhkan solusi yang tepat agar dapat diselesaikan dengan efektif. Melihat situasi dan kebutuhan anak maka orangtua dan lingkungan diharapkan mampu membantu dengan 
memberikan sebuah kegiatan yang sesuai dengan kebutuhan anak akan bermain sekaligus mampu berinteraksi dengan teman sebaya dan lingkungannya. Maka sewajarnya jika sebagai orangtua memiliki tugas dan tanggungjawab untuk menfasilitasi berkembangnya kemampuan sosial emosi anak.

Kegiatan seni yang diajarkan di sekolah PAUD memiliki berbagai cabang seni, namun guna efektititas stimulasi sosial emosi anak perlu dipilihkan cabang seni yang mampu mengakomodir situasi dan kondisi anak. Seni tari merupakan cabang seni yang mempergunakan media tubuh sebagai ungkapan estetisnya, pengungkapan nilai estetis tersebut tertuang dalam gerak tubuh manusia (Agustiningrum, 2016).

Anak sebagai seorang individu yang senang melakukan aktifitas bergerak dalam upaya mengekspresikan isi hatinya. Hal tersebut selaras dengan esensi dari seni tari itu sendiri, dimaknai sebagai sebuah ekspresi dari manusia. Melalui bergerak pula anak-anak mempelajari sesuatu, dikarenakan gerak menjadi sebuah sarana anak belajar dan mendapatkan sebuah ketrampilan maupun ilmu pengetahuan (Agustinigrum \& Rohendi, 2020).

Pembelajaran tari bagi anak usia dini adalah salah satu dari kegiatan yang biasa dilakukan baik di sekolah maupun di sanggar. Adapun bentuk tari yang dipergunakan biasanya adalah tari-tari yang khusus diciptakan untuk anak. secara khusus pemilihan taritari tersebut agar dapat ditarikan secara efektif oleh anak sebaiknya mempertimbangkan kebutuhan anak.

\section{METODOLOGI}

Penelitian ini memilih mempergunakan metode penelitian kualitatif dikarenakan penelitian kualitatif mampu menceritakan secara detail tingkah laku dan proses pembelajaran dengan lebih detail sesuai dengan fakta yang ditemui di lapangan. Metode penelitian yang dipergunakan adalah jenis penelitian kualitatif yang memiliki tujuan untuk mendeskripsikan tari Nawung Sekar sebagai sebuah kegiatan berkesenian anak sekaligus bermain anak yang diungkapkan secara textual maupun kontekstual. Penggunan pendekatan kualitatif dikarenakan penelitian ini mempelajari manusia dan prilakunya sehingga tidak bisa diukur dalam skala angka namun hasil penelitian dipergunakan dalam bentuk narasi.

Pendekatan penelitian yang digunakan adalah pendekatan multidisiplin dengan jenis penelitian sosial-antropologi tari yang memandang tari Nawung Sekar sebagai produk budaya lokal, yaitu: tari klasik putri gaya Yogyakarta. Pendekatan yang dipakai adalah pendekatan historis dan pendekatan fungsional kemudian penentuan fungsi-fungsi dari suatu fenomena sosial. Pendekatan Seni tari digunakan untuk mendeskripsikan dan menganalisa struktur/bentuk tari Nawung Sekar sebagai produk seni tari yang memiliki nilai estetik (Denok et al., 2017).

Bidang ilmu psikologi perkembangan digunakan untuk menganalisis kemampuan berinteraksi anak sebagai sebuah tugas belajar kemampuan sosial emosi anak. Teori ini dipergunakan dalam upaya memposisikan anak dengan tepat sesuai dengan tahapan perkembangannya.

Subyek penelitian ini adalah anak-anak perempuan yang berusia 5-6 tahun yang berlatih tari Nawung Sekar di sanggar tari Yayasan Pamulangan Beksa Sasminta Mardawa Yogyakarta sejumlah 15 anak perempuan. Pemilihan lokasi dengan alas an bahwa proses pendidikan pada anak usia dini dapat dilakukan pada lembaga-lembaga formal maupun nonformal. Walaupun pada kenyataannya tari Nawung Sekar juga dipelajari di sekolahsekolah formal sebagai bagian dari materi pelajaran namun pada penelitian ini peneliti mengambil sanggar sebagai lembaga nonformal dengan alasan sanggar tari Yayasan Pamulangan Beksa Sasminta Mardawa Yogyakarta merupakan sanggar yang mengajarkan tari Nawung Sekar sebagai materi pembelajaran untuk pertama kalinya dan terbukti menciptakan penari-penari klasik gaya Yogyakarta yang mumpuni dan berkompeten. 
Pengambilan data penelitian dengan mempergunakan wawancara, observasi dan studi dokumentasi pada beberapa sumber penelitian dan kemudian dianalisis menurut Milles and Huberman yang dapat dilihat pada gambar 1.

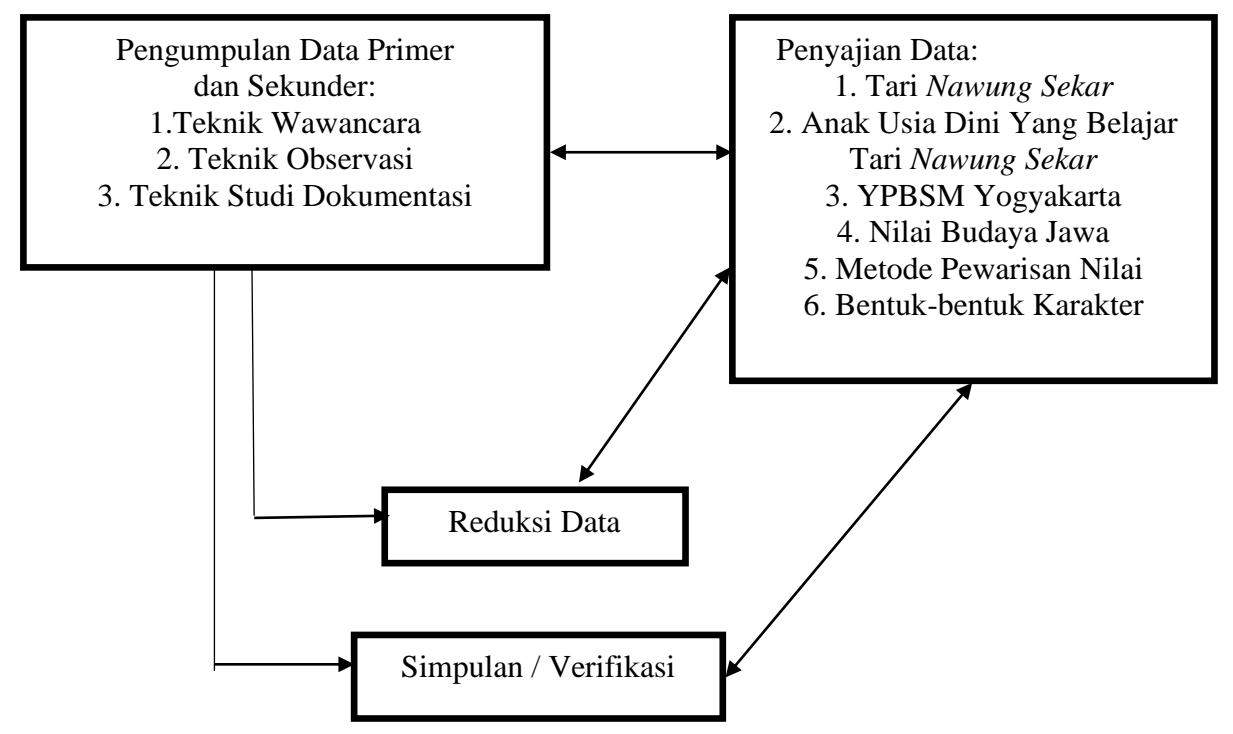

Sumber: Milles \& Huberman (1984)

Gambar 1. Analisis menurut Milles and Huberman

\section{HASIL DAN PEMBAHASAN}

Penelitian ini menemukan bahwa tari Nawung Sekar adalah bagian dari tari klasik putri gaya Yogyakarta yang dipelajari oleh anak-anak, sebuah fenomena yang terwujud sebagai keinginan untuk terus melanggengkan kebudayaan jawa khususnya. Menjadi sebuah yang patut untuk diungkap karena nilai-nilai budaya jawa mampu mengejawantah dalam tari Nawung Sekar dan dipelajari oleh anak-anak usia dini pada jaman teknologi terlebih pada era revolusi industry 4.0 .

Anak usia dini sebagai seorang individu kelak dewasa memiliki peran dalam sebuah komunitas masyarakat, sehingga memiliki peran sebagai penyangga identitas budaya. Sebagai individu maka anak usia dini akan terus belajar untuk mengolah segala perasaan, hasrat nafsu, dan emosi kemudian menjadi sebuah kepribadian. Kepribadian inilah yang menjadi modal seorang anak usia dini saat dewasa kelak dapat diterima oleh masyarakat. Proses internalisasi ini merupakan proses yang dilakukan seumur hidup individu bersama masyarakat atau komunitasnya, dapat diartikan bahwa proses internalisasi ini merupakan proses yang harus terus-menerus dan berkesinambungan sehingga hasil akhirnya dapat sesuai dengan yang diharapkan (Agustinigrum, 2017).

Proses pembelajaran yang dilakukan untuk mempelajari tari Nawung Sekar membutuhkan waktu 6 bulan dari awal hingga pementasan dengan frekuensi Latihan 2x dalam tiap minggu sampai pementasan / anak menguasai tarian tersebut. Maka dalam proses tersebut terjadi banyak interaksi sosial antara guru dengan anak, antar anak dengan anak lain yang berada dalam usia yang sama dan antar anak dengan orangtua. Dari proses tersebut ditemukan hasil pembelajaran tari Nawung Sekar efektif sebagai kegiatan berinteraksi sosial untuk anak dikarenakan tari Nawung Sekar memiliki durasi waktu yang pendek (5.55') sehingga mudah dilakukan anak usia dini, karena sesuai dengan tahap perkembangan kemampuan kognitif anak usia dini memiliki rentang kemampuan konsentrasi anak usia dini yaitu $5^{\prime} \mathrm{s} / \mathrm{d} 10^{\prime}$; dari proses pembelajaran ini anak mampu belajar untuk berkonsentrasi dan fokus (Hurlock, 2006). 
Gerakan-gerakan yang ada pada tari Nawung Sekar tidak memiliki detail gerak jari yang rumit sehingga anak usia dini mudah untuk menirukan atau melakukan gerakannya. Hal tersebut sesuai dengan tahap perkembangan anak dikarenakan kemampuan motorik halus anak usia dini berada pada tahap kemampuan menggenggam, menjumput, meremas sehingga bentuk-bentuk gerak tari yang memerlukan bentuk jari yang detail sulit untuk dilakukan anak.

Gerakan-gerakan yang ada pada tari Nawung Sekar sederhana namun berulang. Gerakan sederhana yang berulang memudahkan anak untuk melakukan dikarenakan kemampuan motorik kasar anak masih dalam tahap perkembangan. Seperti kemampuan berjinjit, pertumpu pada satu kaki secara bergantian, mengayun, berlari kecil-kecil. Pada tari Nawung Sekar beberapa gerakan sederhana dan berulang sehingga sesuai dengan tahap perkembangan kemampuan motorik kasar anak usia dini. Pengulangan gerak-gerak dalam tari Nawung Sekar tanpa detail rumit mampu menstimulasi kemampuan sosial emosi yaitu pada tahap mempelajari kesabaran (Zaman, 2010).

Hitungan pada tari Nawung Sekar mempergunakan gendhing Lancaran yaitu $1 \mathrm{~s} / \mathrm{d} 8$ hitungan atau $1 \mathrm{~s} / \mathrm{d} 16$ hitungan dan berulang sehingga memudahkan anak usia dini untuk menghafal dikarenakan sesuai dengan tahap perkembangan anak kemampuan kognitif anak yaitu mampu berhitung dari $1 \mathrm{~s} / \mathrm{d} 20$ hitungan. Pada tahap ini anak terstimulasi memiliki ekspresi atau mood yang sama yaitu riang, karena sifat dari dari gendhing lancaran adalah ringan.

Pola lantai yang terdapat pada tari Nawung Sekar sesuai pakem tari klasik gaya Yogyakarta namun sederhana sehingga anak mudah mengingat dan melakukannya, yaitu samping kanan, tengah dan samping kiri. Hal tersebut dapat dipergunakan untuk menstimulasi konsep kanan-kiri, depan-belakang yaitu konsep arah kepada anak usia dini. Kemampuan sosial emosi yang terstimulasi pada proses mempelajari pola lantai ini adalah bagaimana anak belajar untuk bergerak dan menghafal posisi dan perpindahan dalam menari tanpa menganggu ruang teman lain yang ada bersama-sama dalam satu pendopo untuk menari, tahapan ini anak belajar bertoleransi antar teman (Putraningsih, 2015).

Tari Nawung Sekar tidak mempergunakan property apapun sehingga memberi ruang kepada anak untuk bebas bergerak dikarenakan tingkat kemampuan fisik motoriknya belom sempurna. Stimulasi kemampuan sosial emosi yang nampak pada proses belajar ini adalah walaupun anak bebas bergerak namun anak belajar berprilaku tari yaitu menjadi postur tubuh mendhak (posisi lutut memayungi kaki dengan paha terbuka) dan badan membusung namun tidak terkesan angkuh atau sombong.

Iringan tari Nawung Sekar ceria dan issie listening sehinggga memberi kesan ceria dan ringan. Penggunaan irama gendhing yang ceria dan ringan sesuai dengan sifat anak usia dini yang menyukai musik-musik yang rancak dikarenakan kecenderungan anak untuk bebas bergerak. Pada pemahaman ini stimulasi kemampuan sosial emosi nampak pada ekspresi senang dan bangga terhadap tiap gerakan namun tetap dalam kontrol yang benar.

Dari ketujuh bahasan estetika tari Nawung Sekar yang dianalisis dengan perkembangan kemampuan sosial emosi anak muncul dalam proses kegiatan belajar mengajar tari Nawung Sekar di sanggar tari Yayasan Pamulangan Beksa Sasminta Mardawa Yogyakarta. Stimulasi sosial emosi muncul dalam proses kegiatan yang lain di sanggar tari Yayasan Pamulangan Beksa Sasminta Mardawa Yogyakarta, seperti pada saat anak belajar menempati tempat di baris depan secara bergantian. Pergantian posissi berlatih tersebut menunjukkan anak mampu memiliki sikap mengantri dan disiplin (Agustinigrum, 2018).

Anak-anak akan belajar bagaimana cara berinteraksi dengan teman-temannya walaupun berbeda usia dan latar belakang. Pada pertemuan kedua latihan anak-anak sudah mendapat teman baru dan berinteraksi antar satu dengan yang lain, hal tersebut nampak pada gambar 2. 




Gambar 2. Anak bercengkrama saat Latihan akan dimulai

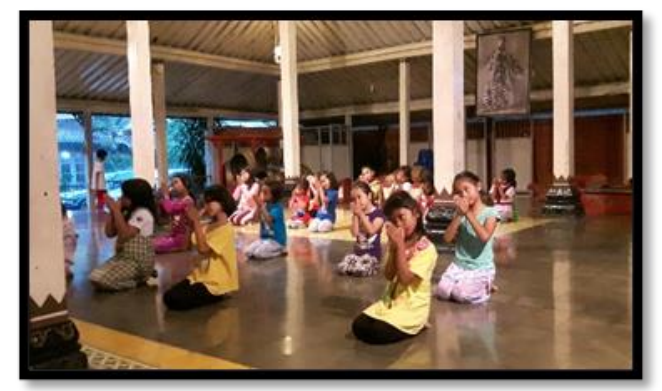

Gambar 3. Posisi Gerak Sembahan

Stimulasi kemampuan sosial emosi juga nampak pada gerakan awal sembahan, dimana anak melakukan gerak sembahan dengan sungguh-sungguh. Sembahan adalah sebuah gerakan yang secara filosofi mengajarkan anak untuk belajar caranya menghormati (Wangsa et al., 2019). Pengenalan sikap menghormati memiliki sebuah makna atau nilai agar anak belajar bagaimana harus bersikap pada orang yang lebih tua dan terlebih bagaimana anak belajar memulai sebuah kegiatan dengan menghormati orang lain yang lebih dulu ada ditempat tersebut. Proses gerak sembahan yang dilakukan oleh anak nampak pada gambar 3. Posisi gerak sembahan adalah gerakan yang dilakukan anak untuk memulai atau mengawali tari Nawung Sekar, yaitu kedua tangan ngruji rapat dengan posisi ibu jari diujung hidung dan keempat jari lainnya menghadap ke atas.

Proses mempelajari tari Nawung Sekar mampu menstimulasi kemampuan sosial emosi anak nampak pada metode belajar melalui teknik wirasa yang tergambar dalam bagan pada gambar 4 .

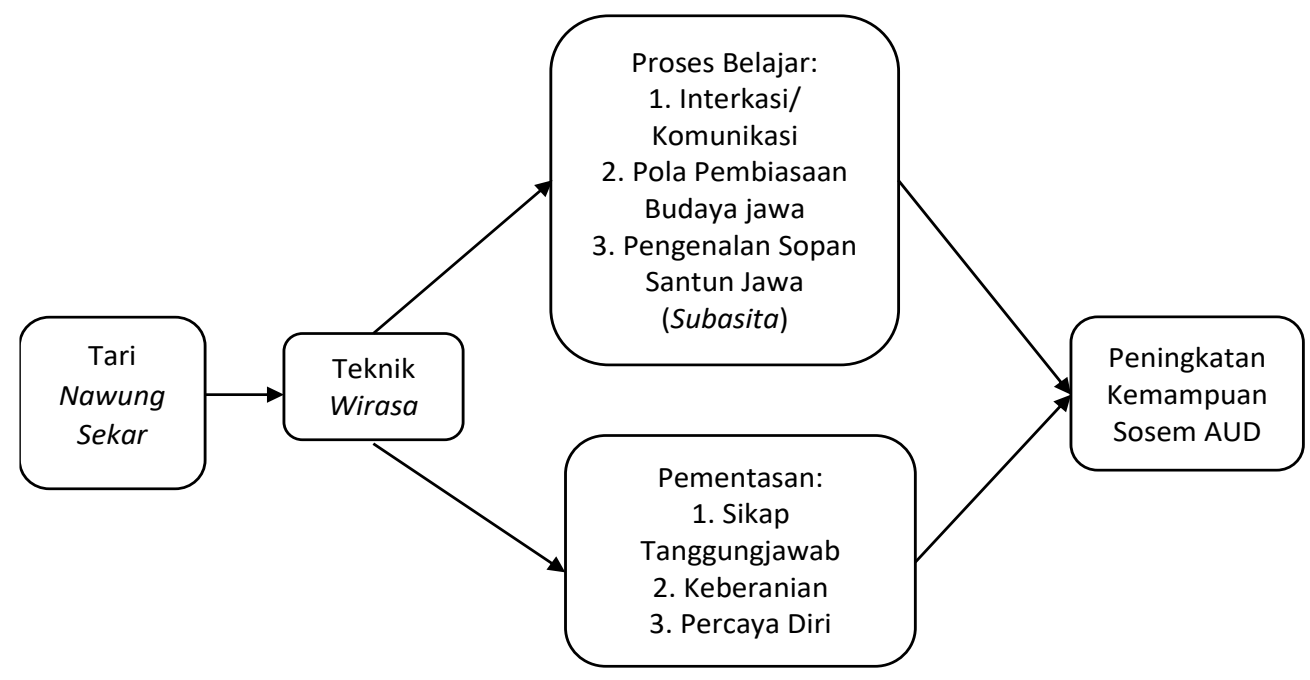

Gambar 4. Bagan Stimulasi Kemampuan Sosial Emosi melalui Teknik Wirasa

Melalui Teknik wirasa menunjukkan bahwa tari Nawung Sekar menstimulasi kemampuan sosial anak yaitu pengenalan sikap tanggungjawab, keberanian dan percaya diri. Diawali dari minat anak usia dini tersebut maka berbagai efek dari pembelajaran tari Nawung Sekar dapat muncul, khususnya terstimulasinya kemampuan sosial anak sehingga terjadi efektifitas (Helsper \& Eynon, 2010). Selanjutnya tahapan perkembangan sosial dapat tercapai melalui tahapan-tahapan seperti yang dapat dilihat pada tabel 1.

Kemampuan sosial yang matang menjadi bekal kemampuan dalam membentuk karakter yang unggul dan berdaya saing disituasi global saat ini. Situasi global yang memberikan tantangan besar bagi berkembangnya karakter anak ke arah yang lebih baik. 
Maka orangtua dan lingkungan berperan aktif untuk membantu terwujudnya karakter yang unggul bagi anak-anak digital natives. Senada dengan temuan itu Ananda et al. (2018) mendapati bahwa perkembangan sosial dapat dikembangkan dengan permainan kolaboratif.

Tabel 1. Pemenuhan Tahapan Perkembangan Sosial menurut Sara Dimerman

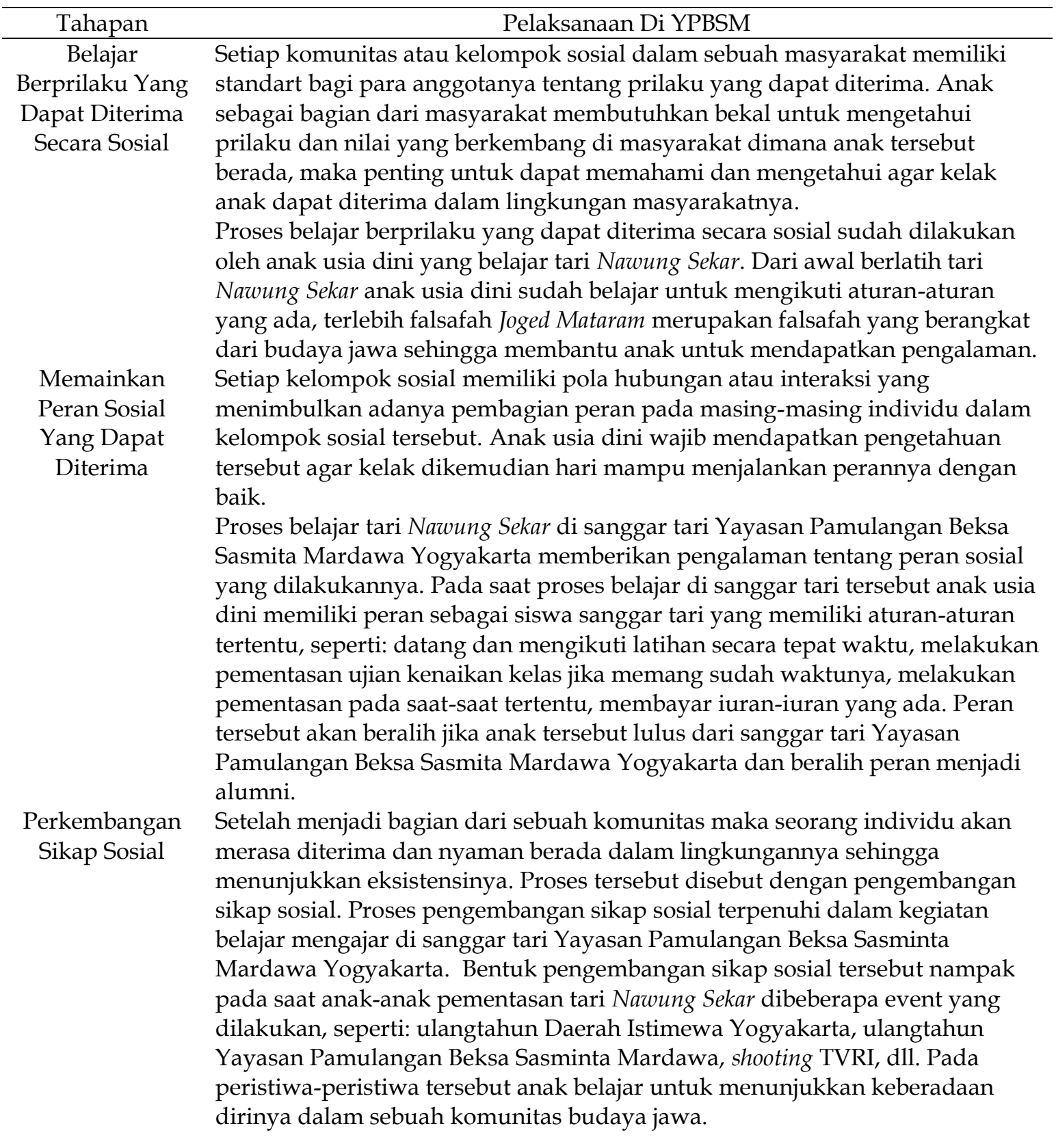

\section{SIMPULAN}

Tari Nawung Sekar sebagai bagian dari tari klasik putri gaya Yogyakarta yang memiliki nilai-nilai karakter masyarakat Indonesia mampu menstimulasi kemampuan sosial emosi anak digital natives yang berada pada situasi jaman revolusi industry 4.0. Ditemukan fakta munculnya beberapa karakter dalam proses belajar tari Nawung Sekar mampu memberi pengalaman anak digital native untuk berinteraksi sosial dengan teman sebayanya. Maka dapat disimpulkan bahwa tari Nawung Sekar merupakan kegiatan seni yang efektif dalam menstimulasi kemampuan sosial anak digital natives di era revolusi industry 4.0 


\section{UCAPAN TERIMA KASIH}

Penelitian ini didanai sepenuhnya oleh Direktorat Riset dan Pengabdian Masyarakat Kementrian Riset dan Teknologi/Badan Riset dan Nasional pada skema Penelitian Disertasi Doktor tahun 2018. Dan juga terimakasih kepada Jurnal Obsesi : Jurnal Pendidikan Anak Usia Dini yang telah memberikan masukan dalam penulisan artikel ini.

\section{DAFTAR PUSTAKA}

Agustinigrum, M. D. B. (2017). Tari nawung sekar sebagai wujud tari pendidikan. 1-7.

Agustinigrum, M. D. B. (2018). Penanaman Proses Pendisplinan Diri Anak Berkebutuhan Khusus (Tuna Rungu Wicara) Dalam Pembelajaran Tari Tradisional. Cakrawala Dini: Jurnal Pendidikan Anak Usia Dini, 5(1). https:/ / doi.org/10.17509/cd.v5i1.10493

Agustinigrum, M. D. B. (2020). Stimulation of Social-Emotional of Children's Digital Natives Through Learning Nawung Sekar Dance. Golden Age : Jurnal Pendidikan Anak Usia Dini, 3(2), 41-47. https:/ / doi.org/10.29313/ga:jpaud.v3i2.5284

Agustinigrum, M. D. B., \& Rohendi, T. (2020). Strategi Pengembangan Motorik Anak Usia 5-8 Tahun dan Penanaman Karakter Tanggung Jawab Melalui Tari Nawung Sekar Info Articles. Sentra Cendekia, 1(1), 15-21. https://doi.org/10.31331/jsc.v1i1.1189

Agustiningrum, M. (2016). Penerapan Pendidikan Karakter Melalui Kegiatan Seni Di Lembaga Paud. sembada, 2(2).

Ananda, R., Fadhilaturrahmi, F., Studi, P., Guru, P., Dasar, S., Pahlawan, U., \& Tambusai, T. (2018). Peningkatan Kemampuan Sosial Emosional Melalui Permainan Kolaboratif pada Anak KB. Jurnal Obsesi: Jurnal Pendidikan Anak Usia Dini, 2, 20-26. https:// doi.org/10.31004/obsesi.v2i1.3

Badu, R. (2011). Pengembangan Model Pelatihan Permainan. Penelitian dan Pendidikan, 8 Nomor 1, 70-77.

Denok, M., Rohendi, T., \& Sayuti, S. (2017). Pamulangan beksa sasminta mardawa yogyakarta 's foundation as a pattern-maintenance organization javanese cultural value. Sentra Cendekia, 2(2).

Gifary, S., \& Kurnia N, I. (2015). Intensitas Penggunaan Smartphone Dan Perilaku Komunikasi (Studi Pada Pengguna Smartphone di Kalangan Mahasiswa Program Studi Ilmu Komunikasi Universitas Telkom). Jurnal Sosioteknologi, 14(2), 170-178. https:// doi.org/10.5614/sostek.itbj.2015.14.2.7

Helsper, E. J., \& Eynon, R. (2010). Digital natives: Where is the evidence? British Educational Research Journal, 36(3), 503-520. https:// doi.org/10.1080/01411920902989227

Hurlock, E. B. (2006). Psikologi Perkembangan: Suatu Pendekatan Sepanjang Rentang Kehidupan. (Penerjemah: Istiwidayanti, Soedjarwo). (5 ed.). Erlangga.

Korde-Nayak, V. (2017). Why is India the world's stillbirth capital: causes and solutions? MMJ - A Journal by MIMER Medical College, Pune, India, 1(1), 1-14. https:// doi.org/10.15713/ins.mmj.3

Putraningsih, T. (2015). Perkembangan Tari Klasik Gaya Yogyakarta Di Era Global. Imaji, 5(1). https:// doi.org/10.21831/imaji.v13i2.6691

Wangsa, B. S., Sulistyo, E. T., \& Suyanto, S. (2019). Makna Budi Pekerti Remaja pada Serat Wulangreh Karya Pakubuwono IV: Pupuh Macapat Durma. Mudra Jurnal Seni Budaya, 34(3), 325-329. https:// doi.org/10.31091/mudra.v34i3.681

Yee jin Shin. (2014). Mendidik Anak Di Era Digital (A. Anissa (ed.)). Noura Books.

Zaman, B. (2010). Pengembangan Alat Permainan Edukatif di Lembaga Pendidikan Anak Usia Dini (PAUD). 